\title{
Nitrogen Fertigation Requirements of Drip-irrigated Strawberries
}

\author{
George J. Hochmuth ${ }^{1}$ \\ Horticultural Sciences Department, P.O. Box 110690, University of Florida, Gainesville, FL 32611-0690
}

Earl E. Albregts ${ }^{1}$ and Craig C. Chandler ${ }^{2}$

Gulf Coast Research and Education Center-Dover, University of Florida, 13138 Lewis Gallagher Road, Dover, FL 33527-9664

\author{
John Cornell ${ }^{1}$ and Jay Harrison ${ }^{3}$ \\ Department of Statistics, P.O. Box 110560, University of Florida, Gainesville, FL 32611
}

Additional index words. plant nutrition, tissue analysis, petiole sap analysis, Fragaria $\times$ ananassa

\begin{abstract}
Strawberries (Fragaria $\times$ ananassa Duch.) were grown in two seasons at Dover, Fla., with polyethylene mulch and drip irrigation. Nitrogen was injected weekly at $0.28(50), 0.56(100), 0.84(150), 1.12(200)$, and $1.40(250) \mathrm{kg} \mathrm{N} / \mathrm{ha} \mathrm{per} \mathrm{day}$ (kg·ha' ${ }^{-1}$ for season) for 'Oso Grande' and 'Sweet Charlie' in 1991-92 season and for 'Oso Grande' and 'Seascape' in 19921993 season. Nitrogen fertilization in 1991-1992, over the range of 0.28 to $1.40 \mathrm{~kg} \mathrm{~N} / \mathrm{ha}$ per day, had no significant effect on early (November to January) strawberry yields. March (the largest production month) yield and total-season yield increased with increasing $\mathrm{N}$ fertilization to 0.76 and $0.54 \mathrm{~kg} \mathrm{~N} / \mathrm{ha}$ per day, respectively. Nitrogen fertilization did not affect yields of strawberry in 1992-93. Fruit firmness and average fruit weight were not affected by $\mathrm{N}$ fertilization from 0.28 to $1.40 \mathrm{~kg} \mathrm{~N} / \mathrm{ha}$ per day. Nitrogen fertilization increased whole leaf $\mathrm{N}$, leaf blade $\mathrm{N}$, and petiole sap nitrate- $\mathrm{N}$ concentrations linearly for most sampling dates in both years. Early yields were greater for 'Sweet Charlie' than 'Oso Grande'. Yields were greater for 'Oso Grande' during March, and total-season yields were similar for both cultivars in 1991-92. 'Oso Grande' had greater early, March, and total yields than 'Seascape' in 1992-93.
\end{abstract}

Florida strawberries are produced during the winter and spring months (November through April) on 2000 ha and had a farm-gate value of \$103 million in the 1992-93 season (Freie and Pugh, 1994). Strawberries are grown in the annual-hill production system on polyethylene-mulched beds (Hochmuth, 1988). Until 1990, most strawberries were irrigated with sprinkler systems and all $\mathrm{P}$ and micronutrients and $25 \%$ of the $\mathrm{N}$ and $\mathrm{K}$ were incorporated in the bed soil. The remaining $\mathrm{N}$ and $\mathrm{K}$ was banded in the center of the bed $6 \mathrm{~cm}$ deep between the two rows of strawberry plants (Albregts and Howard, 1984; Hochmuth, 1988).

Strawberry producers have recently changed from sprinkler to drip irrigation to benefit from the water application efficiencies of drip irrigation (Albregts et al., 1990; Locascio and Myer, 1975). Sprinklers are still used to aid establishment of transplants and for frost protection, however most growers now use drip systems to supply water for crop growth requirements as drip irrigation can provide a $70 \%$ savings in water application compared to sprinkler systems (Locascio and Myer, 1975; Locascio et al., 1977). Although drip irrigation has been shown to provide substantial water efficiencies, there is limited information on fertilizer use with drip irrigated strawberries.

Early fertilization research with strawberry was conducted with sprinkler irrigation prior to the mid 1970s. In California, most strawberry cultivars responded to $\mathrm{N}$ between 112 and $170 \mathrm{~kg} \mathrm{~N} / \mathrm{ha}$, although an occasional response to more $\mathrm{N}$ was reported (Cannell et al., 1961; Voth et al., 1961, 1967). Work in Florida demonstrated

Received for publication 31 July 1995. Accepted for publication 14 Feb. 1996. Use of trade names does not imply endorsement of products named nor criticism of similar ones not named. Florida Agricultural Experiment Station journal series no. $\mathrm{R}-04289$. The cost of publishing this paper was defrayed in part by the payment of page charges. Under postal regulations, this paper therefore must be hereby marked advertisement solely to indicate this fact.

${ }^{1}$ Professor.

${ }^{2}$ Associate professor.

${ }^{3}$ Statistican. responses to $\mathrm{N}$ in the same range as the California range although there were reports of responses to lesser amounts of $\mathrm{N}$ (Albregts and Howard 1987, 1988; Albregts et al., 1989, 1990; Albregts and Sutton, 1971; Locascio and Saxena, 1967; Locascio et al., 1977).

As $\mathrm{N}$ rate increased over the range of 50 to $200 \mathrm{~kg} \mathrm{~N} / \mathrm{ha}$, fruit tissue shear resistance increased and titratable acidity decreased (Saxena and Locascio, 1968). Excessive N rates were reported to lead to poorer fruit quality including pale color and soft fruit (Albregts and Howard, 1982; Albregts et al., 1991b; May and Pritts, 1990; Voth et al., 1967).

Work with drip irrigation for strawberries in Florida began in the early 1970s and it became apparent that strawberry yields with drip irrigation were the same as yields with sprinkler irrigation but with one-third the amount of water (Locascio and Myer, 1975; Locascio et al., 1977). Strawberry yields increased when up to 50\% of the $\mathrm{N}$ and $\mathrm{K}$ fertilizer was injected (fertigated) through the drip irrigation system in daily or weekly applications compared to when all $\mathrm{N}$ and $\mathrm{K}$ was applied to the soil preplant (Locascio et al., 1977; Locascio and Martin, 1985). Preplant fertilization of dripirrigated strawberries did not increase yield in another study where $1.12 \mathrm{~kg} \mathrm{~N}$ and $0.92 \mathrm{~kg} \mathrm{~K} /$ ha were injected twice weekly for the season (Albregts et al., 1991a).

The above research results showed that strawberries can be successfully grown with drip irrigation and fertigation in Florida. With sprinkler irrigation, $\mathrm{N}$ requirements of strawberries were between 112 and $224 \mathrm{~kg} \cdot \mathrm{ha}^{-1}$ with reduced fruit quality resulting from higher $\mathrm{N}$ rates. Many Florida strawberry growers inject an average of 1.5 to $2.0 \mathrm{~kg} \mathrm{~N} / \mathrm{ha}$ per day for the season while the recommended rate has been $1.0 \mathrm{~kg} \mathrm{~N} / \mathrm{ha}$ per day (Hochmuth, 1988). More exact $\mathrm{N}$ requirements of fertigated strawberries are not known, however. With the rapid movement of the Florida strawberry industry to drip irrigation, information is needed on management of $\mathrm{N}$ injection through the season with drip irrigation systems. These studies were conducted to determine $\mathrm{N}$ requirements for strawberries grown with drip irrigation and $\mathrm{N}$ fertigation. 


\section{Materials and Methods}

Strawberry fertilization research was conducted during the production seasons of 1991-92 and 1992-93 at the Univ. of Florida Agricultural Research and Education Center at Dover, Fla., on a Seffner fine sand (sandy, siliceous, hyperthermic Quartzipsammentic Haplumbrept) with about $1.0 \mathrm{~g} \cdot \mathrm{kg}^{-1}$ organic matter. Soil preparation at the research site both seasons began in the summer with the incorporation by rototilling of an unfertilized sorghum-sudan hybrid ('Sweet leaf') cover crop. The rototilling was done four times starting in late July to facilitate decomposition of organic matter from the cover crop. Samples of the soil to the 15$\mathrm{cm}$ depth were taken after the final rototilling and were analyzed for $\mathrm{pH}$, and for extractable $\mathrm{P}, \mathrm{K}, \mathrm{Ca}$, and $\mathrm{Mg}$ using the Mehlich-1 extracting solution (Hanlon and DeVore, 1989). Soil nitrate-N concentration was not measured for use as a predictor of fertilizer$\mathrm{N}$ requirement because the current soil nitrate-N status can change momentarily in sandy soils in a humid, high-rainfall region. There are few studies that have successfully assessed the relationship of preplant soil nitrate- $\mathrm{N}$ to fertilizer $\mathrm{N}$ needs for crops in humid regions (Stanford, 1982). Since soil nitrate-N measurement in sandy soils in humid regions is an unreliable predictor of soil $\mathrm{N}$ supplying capacity, many soil testing laboratories substitute a measurement of soil organic matter concentration as an estimate of $\mathrm{N}$ mineralization potential (Black, 1992).

On 16 Sept. 1991 and 14 Sept. 1992, fertilizer was broadcast in the future bed areas. Fertilizer was $10 \mathrm{~kg} \mathrm{Mg} / \mathrm{ha}$ from magnesium sulfate, $20 \mathrm{~kg} \mathrm{P} / \mathrm{ha}$ from triple superphosphate, and $1 \mathrm{Cu}-1 \mathrm{~B}-$ $2 \mathrm{Mn}-2 \mathrm{Zn}-3 \mathrm{Fe}\left(\mathrm{kg} \cdot \mathrm{ha}^{-1}\right)$ from sulfate-containing micronutrient fertilizers (B was supplied from sodium borate). Soil was formed into beds, fumigated with $440 \mathrm{~kg} \cdot \mathrm{ha}^{-1}$ (broadcast rate) of $98 \%$ methyl bromide : $2 \%$ trichloronitromethane (chloropicrin), and pressed with a bed press. During bed pressing, drip irrigation tubing (T-Systems, San Diego, Calif.) was positioned in the center of the bed and buried $2 \mathrm{~cm}$ deep. Drip irrigation tubing emitters were spaced $30 \mathrm{~cm}$ apart and had a flow rate of $19 \mathrm{ml} \cdot \mathrm{min}^{-1}$ at $55 \times 10^{3} \mathrm{~Pa}$. Pressed beds were finally covered with black polyethylene mulch $(0.025 \mathrm{~mm}$ thick). Beds were spaced $122 \mathrm{~cm}$ apart (bed center to bed center). The bed top surface was $60 \mathrm{~cm}$ wide and beds were $15 \mathrm{~cm}$ high.

On 14 Oct. 1991, 'Oso-Grande' and 'Sweet Charlie' bareroot transplants were planted through the mulch in two rows on each bed with $30 \mathrm{~cm}$ between rows and $28 \mathrm{~cm}$ between plants in a row. Plots (experimental units) consisted of $3.4 \mathrm{~m}$ of bed containing 20 plants. The experimental design was a split plot arranged in five randomized complete blocks each season with $\mathrm{N}$ fertilization rates as main-plot treatments and cultivars as subplot treatments. 'OsoGrande' and 'Seascape' were planted in 1992. 'Oso-Grande' and 'Seascape' were developed in California while 'Sweet Charlie' is an early-fruiting cultivar developed by the Univ. of Florida. 'Oso Grande' is widely grown in Florida while 'Seascape' was used because it was thought to hold promise for commercial culture. 'Sweet Charlie' is a very popular cultivar in Florida. 'Sweet Charlie' plants were grown at the research center in Dover, Fla., and 'Oso-Grande' and 'Seascape' were grown in Canada (Ghesquiere Farms, Simco, Ontario). Transplants were irrigated with overhead sprinklers intermittently each day between 10:00 AM and 4:00 PM for 2 weeks following transplanting to aid plant establishment.

Fertilizer treatments ( $\mathrm{N}$ rates) were $0.28,0.56,0.84,1.12$, and $1.40 \mathrm{~kg} \mathrm{~N} / \mathrm{ha}$ per day with seven times the daily rate applied through the drip system once per week. Fertilizer injection began on 21 Oct. 1991 and ended on 30 Apr. 1992 and, for the second season, began on 18 Oct. 1992 and ended on 30 Apr. 1993. Total season $\mathrm{N}$ applications were 50,100,150, 200, and $250 \mathrm{~kg} \mathrm{~N} / \mathrm{ha}$. With each Ninjection, $0.84 \mathrm{~kg} \mathrm{~K} / \mathrm{h}$ a per day was included. N source was a urea and ammonium nitrate solution $\left(16 \%\right.$ urea- $\mathrm{N}, 8 \% \mathrm{NH}_{4^{-}}$ $\mathrm{N}$, and $8 \% \mathrm{NO}_{3}-\mathrm{N}$ ) and $\mathrm{K}$ source was potassium chloride. Drip irrigation system was operated periodically for irrigation purposes to maintain soil moisture tension between -5 and $-15 \mathrm{kPa}$ (measured by a tensiometer with the ceramic tip at $15 \mathrm{~cm}$ below the surface of the bed between two plants in a row). Foliar and fruit diseases were controlled with timely sprays of captan $(\mathrm{N}-$ trichloromethylthio-4-cyclohexene-1,2-dicarboximicle), iprodione (Vinclozolin [3-(3,5-dichlorophenyl)-5-ethenyl-5-methyl-2,4oxazolidimedione]), and elemental sulfur.

Whole-leaf (blades plus petiole) samples of the most-recently fully expanded leaf from 20 plants in each plot were collected on 19 Nov., 9 and 31 Dec. 1991, and on 18 Feb., 23 Mar., and 13 Apr. in 1992 and on 14 Dec. 1992, 4 and 25 Jan., 16 Feb., 9 and 31 Mar., and 14 Apr. in 1993. Samples consisting of leaf blades only were collected on 14 Dec. 1992, and on 4 Jan., 25 Jan., 16 Feb., 9 Mar., 31 Mar., and 14 Apr. 1993. Leaf petioles were excised from 10 leaves randomly selected from the original sample of 20 leaves. The petioles were chopped and the sap expressed by a hydraulic press (HACH Co., Loveland, Colo.). The fresh petiole sap was analyzed for nitrate-N and $\mathrm{K}$ using battery-operated, hand-held ion specific electrodes (Horiba, Kyota, Japan). The remaining 10 whole leaves were dried in an oven at $65^{\circ} \mathrm{C}$ for 3 days, ground in a Wiley mill, and a 0.5-g sample was digested in sulfuric acid and hydrogen peroxide. Total $\mathrm{N}$ was determined by rapid flow colorimetry (Hanlon and Devore, 1989; Jones, 1977).

Fruit with at least $75 \%$ red color were harvested twice weekly and separated into marketable and cull grade categories. Marketable fruit were those fruit free of rot, well-shaped (conical or flatwedge), and weighing $10 \mathrm{~g}$ or more. Fruit from each harvest in each grade category were counted and weighed. Harvesting for 'Sweet Charlie' and 'Oso Grande' in the first season began on 19 Dec. 1991 and ended on 30 Apr. 1992. Harvesting for 'Seascape' and 'Oso Grande' began on 9 Nov. 1992 and 4 Jan. 1993 respectively, in the second season and ended on 30 Apr. 1993. Firmness of fully ripe 'Seascape' and 'Oso Grande' fruit was measured with a Chatillon model DPP press with a 6-mm wedge-shaped tip. Firmness measurements were made on the side of the fruit when the tip punctured the fruit to a depth of $3 \mathrm{~mm}$. Firmness measurements were made on 25 Feb., 25 Mar., and 8 Apr. 1993.

Early, March, and total season yields as well as leaf and petiole data were analyzed separately for each season since 'Oso Grande'

Table 1. Monthly rainfall and temperature averages for the two seasons of strawberry production.

\begin{tabular}{|c|c|c|c|c|c|c|c|c|}
\hline & Oct. & Nov. & Dec. & Jan. & Feb. & Mar. & Apr. & Season \\
\hline 1991-92 Rainfall (mm) & 16 & 43 & 40 & 37 & 112 & 42 & 58 & Total $=348$ \\
\hline Temperature $\left({ }^{\circ} \mathrm{C}\right)^{\mathrm{z}}$ & 23.8 & 18.1 & 18.5 & 15.1 & 18.0 & 19.5 & 20.9 & Avg. $=19.0$ \\
\hline 1992-93 Rainfall (mm) & 78 & 60 & 22 & 128 & 52 & 112 & 80 & Total $=532$ \\
\hline Temperature $\left({ }^{\circ} \mathrm{C}\right)$ & 22.5 & 21.2 & 17.2 & 19.0 & 15.5 & 17.6 & 19.7 & Avg. $=19.0$ \\
\hline
\end{tabular}

${ }^{\mathrm{z}}$ Temperature recorded $60 \mathrm{~cm}$ above soil surface in protected recording box. 
Table 2. Effects of $\mathrm{N}$ fertilization and cultivar on yields and fruit quality and size of strawberry in two seasons at Dover, Fla.

\begin{tabular}{|c|c|c|c|c|c|c|c|c|c|}
\hline \multirow[b]{3}{*}{$\begin{array}{l}\text { N rate } \\
\left(\mathrm{kg} \cdot \mathrm{ha}^{-1} \cdot \mathrm{d}^{-1}\right)\end{array}$} & \multicolumn{9}{|c|}{ Harvest period } \\
\hline & \multicolumn{3}{|c|}{ Early $^{\mathrm{z}}$} & \multicolumn{3}{|c|}{ March } & \multicolumn{3}{|c|}{ Total } \\
\hline & $\begin{array}{c}\text { Mkt. yield } \\
\left(\mathrm{t} \cdot \mathrm{ha}^{-1}\right)\end{array}$ & $\begin{array}{l}\text { Avg. } \\
\text { fruit wt } \\
(\mathrm{g})\end{array}$ & $\begin{array}{c}\text { Cull } \\
\left(\mathrm{t} \cdot \mathrm{ha}^{-1}\right)\end{array}$ & $\begin{array}{c}\text { Mkt. yield } \\
\left(\mathrm{t} \cdot \mathrm{ha}^{-1}\right)\end{array}$ & $\begin{array}{l}\text { Avg. } \\
\text { fruit wt } \\
(\mathrm{g})\end{array}$ & $\begin{array}{c}\text { Cull } \\
\left(\mathrm{t} \cdot \mathrm{ha}^{-1}\right)\end{array}$ & $\begin{array}{c}\text { Mkt. yield } \\
\left(\mathrm{t} \cdot \mathrm{ha}^{-1}\right)\end{array}$ & $\begin{array}{l}\text { Avg. } \\
\text { fruit wt } \\
(\mathrm{g})\end{array}$ & $\begin{array}{c}\text { Cull } \\
\left(\mathrm{t} \cdot \mathrm{ha}^{-1}\right)\end{array}$ \\
\hline \multicolumn{10}{|c|}{ 1991-92 } \\
\hline 0.28 & 5.96 & 19.5 & 0.45 & 8.94 & 15.0 & 3.36 & 26.36 & 17.4 & 7.78 \\
\hline 0.56 & 6.70 & 19.5 & 0.51 & 11.86 & 16.0 & 3.86 & 32.29 & 18.0 & 8.56 \\
\hline 0.84 & 6.82 & 20.5 & 0.58 & 12.31 & 15.0 & 4.39 & 32.00 & 18.3 & 9.34 \\
\hline 1.12 & 6.53 & 20.5 & 0.58 & 11.27 & 15.0 & 4.08 & 30.73 & 18.2 & 8.98 \\
\hline 1.40 & 7.22 & 19.5 & 0.55 & 12.33 & 15.0 & 4.50 & 32.26 & 17.8 & 9.42 \\
\hline ANOVA & NS & NS & NS & $* \mathrm{y}$ & NS & $* *$ & $*$ & NS & $* *$ \\
\hline \multicolumn{10}{|l|}{ Cultivar } \\
\hline Sweet Charlie & 7.80 & 22.5 & 0.77 & 9.28 & 14.0 & 4.95 & 29.80 & 18.5 & 10.66 \\
\hline Oso Grande & 5.50 & 17.5 & 0.30 & 13.40 & 16.0 & 3.12 & 31.65 & 17.4 & 6.99 \\
\hline ANOVA & $* *$ & $* *$ & $* *$ & $* * \mathrm{y}$ & $* *$ & $* *$ & NS & $* *$ & $* *$ \\
\hline \multicolumn{10}{|c|}{$1992-93$} \\
\hline 0.28 & 8.65 & 13.6 & 0.96 & 14.63 & 17.6 & 1.80 & 34.63 & 14.4 & 6.53 \\
\hline 0.56 & 8.83 & 13.3 & 1.02 & 16.36 & 17.8 & 2.26 & 38.06 & 14.4 & 7.80 \\
\hline 0.84 & 9.02 & 13.3 & 1.14 & 17.21 & 18.2 & 2.00 & 39.83 & 14.7 & 7.47 \\
\hline 1.12 & 8.66 & 13.8 & 0.92 & 17.05 & 18.1 & 2.21 & 38.68 & 14.9 & 7.61 \\
\hline 1.40 & 8.88 & 13.7 & 0.94 & 17.07 & 18.1 & 2.38 & 40.24 & 15.0 & 8.32 \\
\hline ANOVA & NS & NS & NS & NS & NS & NS & NS & NS & NS \\
\hline \multicolumn{10}{|l|}{ Cultivar } \\
\hline Oso Grande & 9.66 & 11.5 & 0.77 & 17.56 & 17.6 & 2.35 & 43.09 & 13.8 & 7.91 \\
\hline Seascape & 7.95 & 15.6 & 1.25 & 15.37 & 18.3 & 1.93 & 33.49 & 15.7 & 7.19 \\
\hline ANOVA & $* *$ & $* *$ & $* *$ & $* *$ & $*$ & $*$ & $* *$ & $* *$ & NS \\
\hline
\end{tabular}

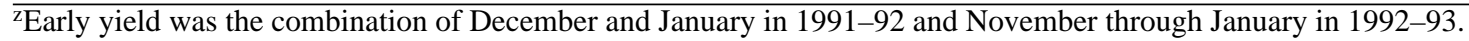

${ }^{\mathrm{y}}$ Rate $\times$ cultivar interaction was significant.

Ns, ${ }^{* * *}$ Nonsignificant or significant at $P=0.05$ or 0.01 , respectively.

was the only cultivar used in both seasons. For each season, the data were analyzed using analysis of variance or PROC ANOVA (SAS Institute, 1982) to determine the effect of $\mathrm{N}$ rate, compare the cultivars, and to see if $\mathrm{N}$ rate interacted with cultivars. When an interaction was present, the effect of $\mathrm{N}$ rate was measured for each cultivar separately. When no interaction was present, the effect of $\mathrm{N}$ rate was measured across both cultivars. The effect of $\mathrm{N}$ rate, when significant $(P<0.05)$, was modeled using linear, quadratic, linear-plateau, and quadratic-plateau models (Anderson and Nelson, 1975; Dahnke and Olson, 1990; Nelson and Anderson, 1977) with the NLIN procedure (SAS Institute, 1982).

\section{Results}

Mehlich-1 soil tests showed very high concentrations of $\mathrm{P}$ and low concentrations of extractable K. Although measurements of soil organic matter were not made for these experiments, recent soil organic matter analyses at this site showed $1.0 \mathrm{~g} \cdot \mathrm{kg}^{-1}$ organic matter by Walkley-Black method (Hanlon and DeVore, 1989). This organic matter concentration in the soil was expected to contribute only in a small manner to the total crop $\mathrm{N}$ requirement and, from previous research at this site, strawberries were known to respond to $\mathrm{N}$ (Albregts and Howard, 1988).

Table 3. March 1992 average marketable fruit yields at each N fertilization rate and cultivar and regression equations fitted to the 'Sweet Charlie' yields.

\begin{tabular}{|c|c|c|}
\hline \multirow{3}{*}{$\begin{array}{l}\mathrm{N} \text { rate } \\
\left(\mathrm{kg} \cdot \mathrm{ha}^{-1} \cdot \mathrm{d}^{-1}\right)\end{array}$} & \multicolumn{2}{|l|}{ Cultivar } \\
\hline & Sweet Charlie & Oso Grande \\
\hline & \multicolumn{2}{|l|}{ March yield $\left(\mathrm{t} \cdot \mathrm{ha}^{-1}\right)$} \\
\hline 0.28 & 7.39 & 10.47 \\
\hline 0.56 & 8.93 & 14.77 \\
\hline 0.84 & 9.54 & 15.07 \\
\hline 1.12 & 10.65 & 11.88 \\
\hline \multirow[t]{7}{*}{1.40} & 9.90 & 14.75 \\
\hline & Simple linear: $\mathrm{Y}=7.27+2.41 \mathrm{~N}\left(R^{2}=0.24\right)$ & NS \\
\hline & Quadratic: $\mathrm{Y}=5.24+8.62 \mathrm{~N}-3.70 \mathrm{~N}^{2}\left(R^{2}=0.31\right)$ & NS \\
\hline & Linear plateau: $\mathrm{Y}=5.86+5.49 \mathrm{~N}$ for $\mathrm{N} \leq 0.76\left(R^{2}=0.29\right)$ & NS \\
\hline & $\mathrm{Y}=10.0$ for $\mathrm{N}>0.76$ & \\
\hline & Quadratic plateau: $\mathrm{Y}=5.45+7.92 \mathrm{~N}-3.29 \mathrm{~N}^{2}$ for $\mathrm{N} \leq 1.20\left(R^{2}=0.30\right)$ & NS \\
\hline & $\mathrm{Y}=10.21$ for $\mathrm{N}>1.20$ & \\
\hline
\end{tabular}



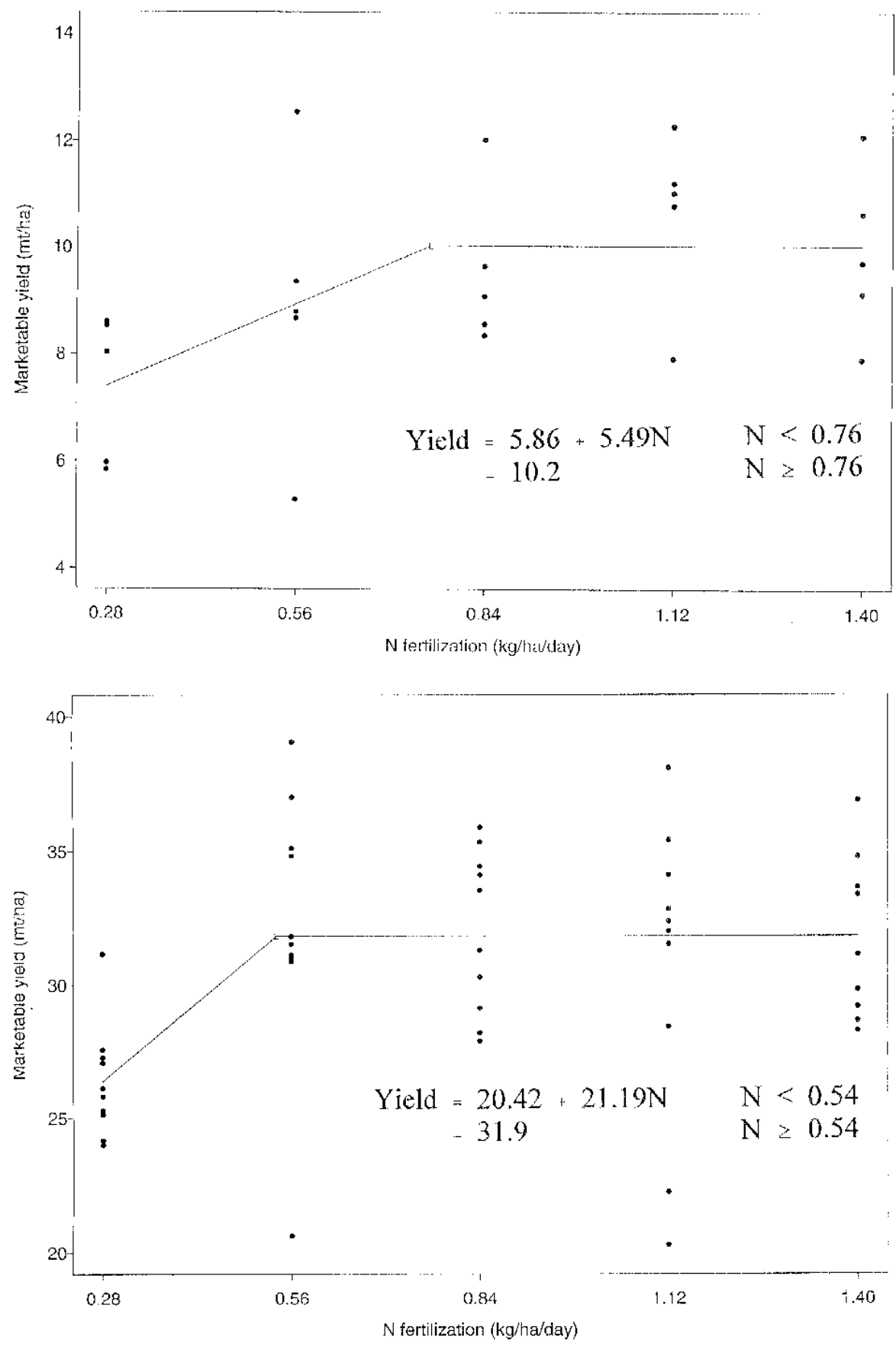

Fig. 1. Linear plateau equation depicting the effect of $\mathrm{N}$ fertilization on yield of 'Sweet Charlie' strawberry during March 1992, Dover, Fla.

higher early yields than 'Oso Grande' in 199192. 'Seascape' had more cull fruit and greater average fruit weight, but lower early marketable yields than 'Oso Grande' in 1992-93.

The highest yielding period during the Florida strawberry season is usually March with as much as one-third of the total crop being harvested in that month. Nitrogen fertilization over the range of 0.28 to $1.40 \mathrm{~kg} \mathrm{~N} / \mathrm{ha}$ per day had no discernible effect on average fruit weight in March 1992 or on marketable yield, average fruit weight, or yield of cull fruit in March 1993 (Table 2). Yield of cull fruit in March 1992 increased with increased N rate (Table 2), a trend previously noted by Albregts and Howard (1982). Nitrogen rate and cultivar interacted in their effects on yield during March 1992. The March marketable yield for 'Sweet Charlie' increased with increased $\mathrm{N}$ fertilization while the yield of 'Oso Grande' was not affected by N (Table 3). 'Oso Grande' had greater yield than 'Sweet Charlie' in March 1992 and greater yield than 'Seascape' in March 1993 (Table 2).

The $\mathrm{N}$ rate $\times$ cultivar interaction with the March 1992 marketable yields was investigated by fitting several types of regression equations, to look for trends in the yields as a function of $\mathrm{N}$ rate, for each cultivar separately. The types of models fitted were simple linear $(\mathrm{SL})$, quadratic $(\mathrm{Q})$, linear plateau $(\mathrm{LP})$, and quadratic plateau (QP). Only in the yields of 'Sweet Charlie' was a trend found with all four models possessing values of $R^{2}$ ranging from 0.24 to 0.31 (Table 3 ). These seemingly low values of $R^{2}$ resulted from modeling five yield values at each $\mathrm{N}$ rate but are reported nonetheless knowing that replicates can lower the value of $R^{2}$ (Cornell and Berger, 1987). Of the four models, our choice is the linear-plateau (Fig. 1) since it fits the data as well as any of the other models tested and predicts a maximum yield of $10.03 \mathrm{t} \cdot \mathrm{ha}^{-1}$ at an $\mathrm{N}$ rate of only 0.76 $\mathrm{kg} \cdot \mathrm{ha}^{-1} \cdot \mathrm{d}^{-1}$. The maximum predicted yields

Fig. 2. Linear plateau equation depicting the effect of $\mathrm{N}$ fertilization on total season (1991-92) strawberry yield, Dover, Fla.

Average seasonal temperature was similar $\left(19{ }^{\circ} \mathrm{C}\right)$ for both years, however, the 1992-93 season received nearly 50\% more rain than the 1991-92 season (Table 1). Temperature and rainfall conditions were considered good for strawberry production with no serious freezes during either season.

Early strawberry yield (Nov. through Jan. period) was not affected by $\mathrm{N}$ fertilization in either season (Table 2). Marketable early fruit yields averaged $6.64 \mathrm{t} \cdot \mathrm{ha}^{-1}$ and $8.80 \mathrm{t} \cdot \mathrm{ha}^{-1}$ during the 1991-92 and 1992-93 seasons, respectively. Average fruit weight and yields of culls also were not affected by $\mathrm{N}$ fertilization over the range of 0.28 to $1.40 \mathrm{~kg} \cdot \mathrm{ha}^{-1} \cdot \mathrm{d}^{-1}$ during the two seasons. 'Sweet Charlie' had more cull fruit, greater average fruit weight, and and $\mathrm{N}$ rates with the other models are $\mathrm{Y}_{\mathrm{SL}}=10.64 \mathrm{t} \cdot \mathrm{ha}^{-1}$ at $\mathrm{N}=1.40$ $\mathrm{kg} \cdot \mathrm{ha}^{-1} \cdot \mathrm{d}^{-1}, \mathrm{Y}_{\mathrm{Q}}=10.26 \mathrm{t} \cdot \mathrm{ha}^{-1}$ at $\mathrm{N}=1.16 \mathrm{~kg} \cdot \mathrm{ha}^{-1} \cdot \mathrm{d}^{-1}$, and $\mathrm{Y}_{\mathrm{QP}}=$ $10.22 \mathrm{t} \cdot \mathrm{ha}^{-1}$ at $\mathrm{N}=1.20 \mathrm{~kg} \cdot \mathrm{ha}^{-1} \cdot \mathrm{d}^{-1}$. Judging by the $\mathrm{N}$ rates estimated to produce the maximum yields, it appears that $\mathrm{N}$ requirements for strawberry during March, the most productive month, are greater than (at least $0.76 \mathrm{~kg} \mathrm{~N} / \mathrm{ha}$ per day) $\mathrm{N}$ requirements at earlier times in the season.

For total-season marketable yield, again our choice among the four types of regression equations is the linear-plateau model $\mathrm{Y}=$ $20.42+21.19 \mathrm{~N}$ for $\mathrm{N} \leq 0.54 \mathrm{~kg} \cdot \mathrm{ha}^{-1} \cdot \mathrm{d}^{-1}$ and $\mathrm{Y}=31.86 \mathrm{t} \cdot \mathrm{ha}^{-1}$ for $\mathrm{N}$ $>0.54 \mathrm{~kg} \cdot \mathrm{ha}^{-1} \cdot \mathrm{d}^{-1}$ (Fig. 2). Maximum predicted total-season yields and $\mathrm{N}$ rates with the other models were, $\mathrm{Y}_{\mathrm{SL}}=32.78 \mathrm{t} \cdot \mathrm{ha}^{-1}$ at $\mathrm{N}=$ $1.40 \mathrm{~kg} \cdot \mathrm{ha}^{-1} \cdot \mathrm{d}^{-1}, \mathrm{Y}_{\mathrm{O}}=32.51 \mathrm{t} \cdot \mathrm{ha}^{-1}$ at $\mathrm{N}=1.05 \mathrm{~kg} \cdot \mathrm{ha}^{-1} \cdot \mathrm{d}^{-1}$, and $\mathrm{Y}_{\mathrm{OP}}$ $=31.80 \mathrm{t} \cdot \mathrm{ha}^{-1}$ at $\mathrm{N}=0.54 \mathrm{~kg} \cdot \mathrm{ha}^{-1} \cdot \mathrm{d}^{-1}$. These maximum yields exceed what has been previously reported (Freie and Pugh, 1994; 
Table 4. Strawberry ('Oso Grande') petiole sap nitrate-N and whole-leaf N concentrations in response to N fertilization of strawberries in two seasons.

\section{$\mathrm{N}$ concn}

\begin{tabular}{|c|c|c|c|c|c|c|c|c|c|c|c|c|c|c|}
\hline $\begin{array}{l}\mathrm{N} \\
\text { applied } \\
\left(\mathrm{kg} \cdot \mathrm{ha}^{-1} \cdot \mathrm{d}^{-1}\right)\end{array}$ & $\begin{array}{l}\text { Petiole } \\
\text { sap } \\
\left(\mathrm{mg} \cdot \mathrm{L}^{-1}\right)\end{array}$ & $\begin{array}{l}\text { Whole } \\
\text { leaf } \\
\left(\mathrm{g} \cdot \mathrm{kg}^{-1}\right)\end{array}$ & $\begin{array}{l}\text { Petiole } \\
\text { sap } \\
\left(\mathrm{mg} \cdot \mathrm{L}^{-1}\right)\end{array}$ & $\begin{array}{c}\text { Whole } \\
\text { leaf } \\
\left(\mathrm{g} \cdot \mathrm{kg}^{-1}\right)\end{array}$ & $\begin{array}{c}\text { Petiole } \\
\text { sap } \\
\left(\mathrm{mg} \cdot \mathrm{L}^{-1}\right)\end{array}$ & $\begin{array}{c}\text { Whole } \\
\text { leaf } \\
\left(\mathrm{g} \cdot \mathrm{kg}^{-1}\right)\end{array}$ & $\begin{array}{l}\text { Petiole } \\
\text { sap } \\
\left(\mathrm{mg} \cdot \mathrm{L}^{-1}\right)\end{array}$ & $\begin{array}{c}\text { Whole } \\
\text { leaf } \\
\left(\mathrm{g} \cdot \mathrm{kg}^{-1}\right)\end{array}$ & $\begin{array}{l}\text { Petiole } \\
\text { sap } \\
\left(\mathrm{mg} \cdot \mathrm{L}^{-1}\right)\end{array}$ & $\begin{array}{l}\text { Whole } \\
\text { leaf } \\
\left(\mathrm{g} \cdot \mathrm{kg}^{-1}\right)\end{array}$ & $\begin{array}{l}\text { Petiole } \\
\text { sap } \\
\left(\mathrm{mg} \cdot \mathrm{L}^{-1}\right)\end{array}$ & $\begin{array}{c}\text { Whole } \\
\text { leaf } \\
\left(\mathrm{g} \cdot \mathrm{kg}^{-1}\right)\end{array}$ & $\begin{array}{l}\text { Petiole } \\
\text { sap } \\
\left(\mathrm{mg} \cdot \mathrm{L}^{-1}\right)\end{array}$ & $\begin{array}{l}\text { Whole } \\
\text { leaf } \\
\left(\mathrm{g} \cdot \mathrm{kg}^{-1}\right)\end{array}$ \\
\hline 1991-92 & \multicolumn{2}{|c|}{19 Nov. } & \multicolumn{2}{|c|}{9 Dec. } & \multicolumn{2}{|c|}{31 Dec. } & \multicolumn{2}{|c|}{18 Feb. } & \multicolumn{2}{|c|}{23 Mar. } & \multicolumn{2}{|c|}{13 Apr. } & & \\
\hline 0.28 & $760^{z}$ & $35.0^{\mathrm{z}}$ & 600 & 29.0 & 560 & 27.6 & 240 & 24.4 & 460 & 25.4 & 420 & 26.0 & & \\
\hline 0.56 & 890 & 39.0 & 700 & 32.5 & 980 & 31.2 & 260 & 27.2 & 450 & 27.0 & 330 & 24.6 & & \\
\hline 0.84 & 860 & 35.5 & 780 & 30.5 & 1050 & 31.2 & 300 & 29.0 & 560 & 27.6 & 400 & 24.8 & & \\
\hline 1.12 & 910 & 36.0 & 820 & 32.0 & 1110 & 31.6 & 360 & 28.2 & 600 & 27.4 & 390 & 25.2 & & \\
\hline 1.40 & 970 & 38.0 & 740 & 31.0 & 1060 & 31.0 & 390 & 28.4 & 580 & 27.8 & 450 & 25.4 & & \\
\hline Regression & NS & NS & NS & NS & $\mathrm{L}^{* *}$ & $\mathrm{~L}^{* *}$ & $\mathrm{~L}^{* *}$ & $\mathrm{~L}^{* *}$ & $\mathrm{~L}^{* *}$ & NS & $\mathrm{L}^{*}$ & NS & & \\
\hline 1992-93 & \multicolumn{2}{|c|}{14 Dec. } & \multicolumn{2}{|c|}{4 Jan. } & \multicolumn{2}{|c|}{25 Jan. } & \multicolumn{2}{|c|}{16 Feb. } & \multicolumn{2}{|c|}{9 Mar. } & \multicolumn{2}{|c|}{31 Mar. } & \multicolumn{2}{|c|}{14 Apr. } \\
\hline 0.28 & 410 & 22.6 & 180 & 23.6 & 150 & 20.2 & 90 & 23.2 & 100 & 22.4 & 150 & 22.6 & 120 & 20.4 \\
\hline 0.56 & 570 & 25.2 & 350 & 25.2 & 180 & 22.4 & 120 & 23.0 & 170 & 23.2 & 210 & 24.2 & 220 & 22.0 \\
\hline 0.84 & 630 & 25.6 & 340 & 24.8 & 210 & 23.0 & 140 & 23.2 & 210 & 23.4 & 130 & 24.2 & 240 & 23.2 \\
\hline 1.12 & 760 & 26.0 & 440 & 25.2 & 180 & 24.6 & 150 & 23.8 & 200 & 24.0 & 160 & 25.4 & 300 & 22.8 \\
\hline 1.40 & 720 & 26.4 & 520 & 25.0 & 230 & 24.2 & 160 & 24.0 & 200 & 24.8 & 210 & 25.0 & 250 & 23.0 \\
\hline Regression & $\mathrm{L}^{* *}$ & $\mathrm{~L}^{* *}$ & $\mathrm{~L}^{* *}$ & NS & NS & $\mathrm{L}^{* *}$ & $\mathrm{~L}^{*}$ & NS & $\mathrm{L}^{* *}$ & NS & NS & $\mathrm{L}^{*}$ & $\mathrm{~L}^{*}$ & $\mathrm{~L}^{*}$ \\
\hline
\end{tabular}

${ }^{\mathrm{z}}$ Values are means of five replicates each season.

Ns,*,*** Nonsignificant or significant test on slope of the simple linear regression equation of yield on $\mathrm{N}$ rate at $P=0.05$ or 0.01 , respectively.

Hochmuth, 1988) as average strawberry yields in Florida of about $13.92 \mathrm{t} \cdot \mathrm{ha}^{-1}$ but are more in line with what growers desire.

With the March 1992 'Sweet Charlie' yield and the total-season yield, the simple linear and quadratic models suggested a need for more $\mathrm{N}$ than was actually required for desired yields. This predicted need for excess $\mathrm{N}$, particularly with the quadratic model, was illustrated in work with other crops (Bullock and Bullock, 1994; Cerrato and Blackmer, 1990; Hochmuth et al., 1993). For total-season yields, the linear plateau and the quadratic plateau models predicted a maximum yield at about $0.5 \mathrm{~kg} \mathrm{~N} / \mathrm{ha}$ per daywith yield leveling off above $0.5 \mathrm{~kg} \mathrm{~N} /$ ha per day. Average fruit weight was not affected by $\mathrm{N}$ rate, while yield of cull fruit at an $\mathrm{N}$ rate of $0.28 \mathrm{~kg} \cdot \mathrm{ha}^{-1} \cdot \mathrm{d}^{-1}$ was lower compared to cull fruit yields at $\mathrm{N}$ rates of 0.56 and higher (Table 2).

Marketable yield for the second season was not affected by $\mathrm{N}$ rate (Table 2). An average of $0.28 \mathrm{~kg} \mathrm{~N} /$ ha per day was sufficient $\mathrm{N}$ to produce maximum yield for the season for both cultivars. The average $\mathrm{N}$ application rate of $0.28 \mathrm{~kg} \cdot \mathrm{ha}^{-1} \cdot \mathrm{d}^{-1}$ resulted in about 50 $\mathrm{kg} \mathrm{N} /$ ha for the typical 180-day season in Florida which is considerably less than the amount of $\mathrm{N}$ currently used by Florida strawberry growers or by growers elsewhere (Kolb, 1986). Average fruit weight and yield of cull fruit for the second season also were not affected by $\mathrm{N}$ fertilization above $0.28 \mathrm{~kg} \mathrm{~N} / \mathrm{ha}$ per day.

Total-season yields for 'Sweet Charlie' and 'Oso Grande' were not different during the first season. 'Oso Grande' had a greater yield than 'Seascape' in the second season. Average fruit weight and cull yield were greater for 'Sweet Charlie' than for 'Oso Grande' during the first season. In the second season, 'Seascape' had higher average fruit weight than 'Oso Grande' but cull yields for the two cultivars were not different.

Fruit firmness was measured in the second season and was not affected by $\mathrm{N}$ fertilization with average firmness values of 1.86 , 1.62, and 1.44 N during February, March, and April, respectively. Fruit firmness was greater in February than March and firmness of fruit in March was greater than fruit firmness in April. 'Oso Grande' plants produced firmer fruit in March (1.70 vs. $1.52 \mathrm{~N})$ and April (1.62 vs. $1.30 \mathrm{~N})$ compared to 'Seascape' but firmness was similar in February (average $=1.86 \mathrm{~N}$ ).

$\mathrm{N}$ analyses of whole leaves (Table 4) and leaf blades (Table 5) showed mostly linear responses of leaf-N concentration to $\mathrm{N}$ fertilization. Nitrogen concentrations in petiole sap and/or whole leaves correlated positively with level of $\mathrm{N}$ fertilization on 11 of 13 sampling dates during the two seasons (Table 4). Leaf blade $\mathrm{N}$ concentration correlated positively with level of $\mathrm{N}$ fertilization on four of seven sampling dates in the second season (Table 5). Adequate ranges for $\mathrm{N}$ concentration in Florida strawberry whole leaves are 30 to $40 \mathrm{~g} \cdot \mathrm{kg}^{-1}$ during October through January, 28 to 30 $\mathrm{g} \cdot \mathrm{kg}^{-1}$ during February through March, and 25 to $30 \mathrm{~g} \cdot \mathrm{kg}^{-1}$ during April (Hochmuth et al., 1991). From December through March of the first season, $\mathrm{N}$ concentrations of strawberry leaves were near

Table 5. Main effects of $\mathrm{N}$ fertilization on $\mathrm{N}$ concentration of strawberry leaf blades, 1992-93 season.

\begin{tabular}{|c|c|c|c|c|c|c|c|}
\hline \multirow{3}{*}{$\begin{array}{l}\mathrm{N} \text { rate } \\
\left(\mathrm{kg} \cdot \mathrm{ha}^{-1} \cdot \mathrm{d}^{-1}\right)\end{array}$} & \multicolumn{7}{|c|}{ Sampling date } \\
\hline & 14 Dec. & 4 Jan. & 25 Jan. & $16 \mathrm{Feb}$. & 9 Mar. & 31 Mar. & 14 Apr. \\
\hline & \multicolumn{7}{|c|}{$\mathrm{N}$ concn $\left(\mathrm{g} \cdot \mathrm{kg}^{-1}\right)$} \\
\hline 0.28 & 25.4 & 25.0 & 20.6 & 23.6 & 24.4 & 25.1 & 23.0 \\
\hline 0.56 & 25.5 & 26.5 & 22.5 & 23.8 & 25.4 & 25.7 & 24.1 \\
\hline 0.84 & 25.4 & 26.6 & 25.0 & 23.9 & 25.5 & 25.8 & 24.3 \\
\hline 1.12 & 26.8 & 27.5 & 25.2 & 24.7 & 26.7 & 26.8 & 26.3 \\
\hline 1.40 & 26.6 & 27.6 & 25.0 & 25.2 & 26.2 & 27.7 & 24.7 \\
\hline Regression & NS & $\mathrm{L}^{* *}$ & $\mathrm{~L}^{* *} \mathrm{Q}^{*}$ & NS & NS & $\mathrm{L}^{* *}$ & $\mathrm{~L}^{*}$ \\
\hline
\end{tabular}

$\overline{\mathrm{Ns},},{ }^{* * *}$ Nonsignificant or significant at $P=0.05$ or $0.001 ; \mathrm{L}=$ linear, $\mathrm{Q}=$ quadratic. 
or slightly below the published adequate ranges for most of the season. Strawberry leaf and blade N concentrations were always slightly below the adequate ranges during the second season. In light of the yield response data, it appears that the current published adequate ranges for $\mathrm{N}$ concentrations in strawberry leaves are too high.

Strawberry leaf petiole fresh sap nitrate-N concentrations, like the leaf-N concentrations, increased linearly with increasing $\mathrm{N}$ fertilization on 9 of 13 sampling dates (Table 4). Published data for adequate ranges for nitrate- $\mathrm{N}$ of fresh strawberry petiole sap were not found. Based on the yield responses to $\mathrm{N}$ in Table 2 and the petiole sap nitrate-N values in Table 4, one might conjecture that adequate petiole sap nitrate-N ranges would be 600 to $900 \mathrm{mg} \cdot \mathrm{L}^{-1}$ in November, decreasing to 100 to $200 \mathrm{mg} \cdot \mathrm{L}^{-1}$ in April.

Results of these studies showed that $\mathrm{N}$ fertilization requirements of Florida strawberries are below currently recommended levels and are considerably less than the rates typically used by many commercial strawberry growers. Early and total-season production was greatest with an average of only 0.28 and $0.56 \mathrm{~kg}$ $\mathrm{N} /$ ha per day, respectively, while at most $0.76 \mathrm{~kg} \cdot \mathrm{ha}^{-1} \cdot \mathrm{d}^{-1}$ was needed by one of the cultivars to maximize the March yield, with March being the most productive month. Using a different strawberry cultivar ('Chandler') with similar cultural practices to ours, Miner et al. (1993a, 1993b) measured yield responses to N in North Carolina. Our results agree with the North Carolina results; N requirement of strawberry grown with drip irrigation and fertigation on polyethylene mulched beds falls in the range of 0.28 to 0.56 $\mathrm{kg} \mathrm{N} /$ ha per day average for the season. These $\mathrm{N}$ rates are about one-fourth to one-half the $\mathrm{N}$ rates currently used by commercial strawberry growers in Florida. Higher $\mathrm{N}$ rates had no measurable effect on average fruit size but did increase numbers of cull fruit.

\section{Literature Cited}

Albregts, E.E., G.A. Clark, C.D. Stanley, F.S.Zazueta, and A.G. Smajstrla. 1991a. Preplant fertilization of fruiting microirrigated strawberry. Hort Science 26:1176-1177.

Albregts, E.E. and C.M. Howard. 1982. Effect of fertilizer rate on number of malformed strawberry fruit. Proc. Fla. State Hort. Soc. 95:323-324.

Albregts, E.E. and C.M. Howard. 1984. Strawberry production in Florida. Fla. Agr. Expt. Sta. Bul. 841.

Albregts, E.E. and C.M. Howard. 1987. Fertilizer rate and method of application on fruiting strawberry. Proc. Fla. State Hort. Soc. 100:198200.

Albregts, E.E., and C.M. Howard. 1988. Effect of fertilizer placement, source, and rate on strawberry fruiting response. Soil Crop Sci. Soc. Fla. Proc. 47:146-149.

Albregts, E.E., C.M. Howard, and C.K. Chandler. 1989. Fertilizer injection into strawberry fruiting beds. Soil Crop Sci. Soc. Fla. Proc. 48:108-111.

Albregts, E.E., C.M. Howard, and C.K. Chandler. 1991b. Effect of high $\mathrm{N}$ rates on fruiting strawberry. Soil Crop Sci. Soc. Fla. Proc. 50:134 136.

Albregts, E.E., C.M. Howard, C.K. Chandler, and F.G. Martin. 1990. Fruiting response of strawberry as affected by rates and sources of controlled-release $\mathrm{N}$ fertilizer, and irrigation method. Soil Crop Sci. Soc. Fla. Proc. 49:46-49.

Albregts, E.E. and P. Sutton. 1971. Response of strawberry to N and K fertilization on a sandy soil. Soil Crop Sci. Soc. Fla. Proc. 31:114-116.

Anderson, R.L. and L.A. Nelson. 1975. A family of models involving intersecting straight lines and concomitant experimental designs useful in evaluating response to fertilizer nutrients. Biometrics 31:303-318.

Black, C.A. 1992. Soil fertility evaluation and control. CRC Press, Boca Raton, Fla.

Bullock, D.G. and D.S. Bullock. 1994. Quadratic and quadratic-plusplateau models for predicting optimal nitrogen rate of corn: A comparison. Agron. J. 86:191-195.
Cannell, G.H., V. Voth, R.S. Bringhurst, and E.L. Proebsting. 1961. The influence of irrigation levels and application methods, polyethylene mulch, and nitrogen fertilization on strawberry production in southern California. Proc. Amer. Soc. Hort. Sci. 78:281-291.

Cerrato, M.E. and A.M. Blackmer. 1990. Comparison of models for describing corn yield response to nitrogen fertilizer. Agron. J. 82:138143.

Cornell, J.A. and R.D. Berger. 1987. Factors that influence the value of the coefficient of determination in simple linear and nonlinear regression models. Phytopathology 77:63-70.

Dahnke, W.C. and R.A. Olson. 1990. Soil test correlation, calibration, and recommendation, p. 45-71. In: R.L. Westerman (ed.). Soil testing and plant analysis. 3rd ed. Soil Sci. Soc. Amer., Madison, Wis.

Freie, R.L. and N.L. Pugh. 1994. Florida Agricultural Statistics-Vegetable summary. Fla. Agr. Stat. Serv., Orlando, Fla.

Hanlon, E.A. and J.M. DeVore. 1989. Institute of Food and Agricultural Sciences Extension soil testing laboratory chemical procedures and training manual. Fla. Coop. Ext. Serv. Circ. 812.

Hochmuth, G.J. (ed.). 1988. Strawberry production guide for Florida. Fla. Coop. Ext. Serv. Circ. 142C.

Hochmuth, G.J., E.A. Hanlon, and J. Cornell. 1993. Watermelon phosphorus requirements in soils with low Mehlich-1 extractable phosphorus. HortScience 28:630-632.

Hochmuth, G., D. Maynard, C. Vavrina, and E. Hanlon. 1991. Plant tissue analysis and interpretation for vegetable crops in Florida. Fla. Coop. Ext. Serv. Spec. Ser. SS-VEC-42.

Jones, Jr., J.B. 1977. Elemental analysis of soil extracts and plant tissue ash by plasma emission spectroscopy. Commun. Soil. Sci. Plant Anal. $8: 345-365$.

Kolb, K.A. 1986. Putting together a balanced commercial strawberry fertilizer program. Proc. N. Amer. Strawberry Growers Assn. p. 41-46.

Locascio, S.J. and F.G. Martin. 1985. Nitrogen source and application timing for trickle-irrigated strawberries. J. Amer. Soc. Hort. Sci. 110:820 823.

Locascio, S.J. and J.M. Myer. 1975. Trickle irrigation and fertilization method for strawberries. Proc. Fla. State Hort. Soc. 88:185-189.

Locascio, S.J., J.M. Myer, and F.G. Martin. 1977. Frequency and rate of fertilization with trickle irrigation for strawberries. J. Amer. Soc. Hort. Sci. 102:456-458.

Locascio, S.J. and G.K. Saxena. 1967. Effects of potassium source and rate and nitrogen rate on strawberry tissue composition and yield. Proc. Fla. State Hort. Soc. 80:173-176.

May, G. and M. Pritts. 1990. Strawberry nutrition. Adv. Strawberry Prod. 9:10-23.

Miner, G.S., E.B. Poling, C.R. Campbell, and D.E. Carroll. 1993a. Influence of $\mathrm{N}, \mathrm{K}_{2} \mathrm{O}$, and drip irrigation on yield and fruit quality of 'Chandler' strawberries. Proc. 2nd Southeastern Strawberry Exposition. p. 1-8. Raleigh, N.C.

Miner, G.S., E.B. Poling, C.R. Campbell, and D.E. Carroll. 1993b. Fertilization requirements of 'Chandler' strawberries under plastic with drip irrigation. Proc. 2nd Southeastern Strawberry Exposition. p. 9-29. Raleigh, N.C.

Nelson, L.A. and R.L. Anderson. 1977. Partitioning of soil-test response probability, p. 19-38. In: T.R. Peck, J.T. Cope, Jr., and D.A. Whitney (eds.). Soil testing: Correlation and interpreting the analytical results. Spec. Publ. 29, Amer. Soc. Agron., Madison, Wis.

Stanford, G. 1982. Assessment of soil nitrogen availability, p. 651-688. In: F.J. Stevenson (ed.). Nitrogen in agricultural soils. Amer. Soc. Agron., Agron. Monogr. 22. Madison, Wisc.

SAS Institute. 1982. SAS users guide: Statistics. SAS Inst., Cary, N.C. Saxena, G.K. and S.J. Locascio. 1968. Fruit quality of fresh strawberries as influenced by nitrogen and potassium nutrition. Proc. Amer. Soc. Hort. Sci. 92:354-362.

Voth, V., E.L. Proebsting, and R.S. Bringhurst. 1961. Response of strawberries to nitrogen in southern California. Proc. Amer. Soc. Hort. Sci. 78:270-274.

Voth, V., K. Uriu, and R.S. Bringhurst. 1967. Effect of high nitrogen applications on yield, earliness, fruit quality, and leaf composition of California strawberries. Proc. Amer. Soc. Hort. Sci. 91:249-256. 